INMR

19,2

Received 2 September 2020 Revised 6 October 2020 Accepted 15 November 2020

\section{Junior enterprise and entrepreneurial behavior in Brazil}

Gustavo Hermínio Salati Marcondes de Moraes State University of Campinas, Campinas, Brazil

Edson Sadao Iizuka

Centro Universitário FEI - Campus São Paulo, São Paulo, Brazil

Anne Kathleen Lopes da Rocha

State University of Campinas, Campinas, Brazil, and

Amanda Mecchi Diaféria

Centro Universitario FEI - Campus São Paulo, São Paulo, Brazil

\begin{abstract}
Purpose - The purpose of this paper is to analyze what is the influence of the junior enterprise environment on the entrepreneurial profile and intention of university students and what is the difference in the entrepreneurial behavior between students who participated and students who did not participate in junior enterprises.

Design/methodology/approach - A quantitative approach based on multivariate data analysis using confirmatory factor analysis and structural equation modeling was applied to a sample of 549 respondents.

Findings - Participation in junior enterprises influences the development of the students' entrepreneurial profile more than their entrepreneurial intention. This study presents which behavioral characteristics are mostly developed with participation in a junior enterprise.

Research limitations/implications - The questionnaire with perception conditions and self-assessment indicators; data collection by a single cross-sectional research design; the scope of the research, which did not use a probabilistic sampling.

Practical implications - Practical implications are to assist higher education institutions in having a more accurate understanding of the role of junior enterprises in stimulating university entrepreneurship. To implement an effective entrepreneurial education, stimulating junior companies can be a fundamental action for the HEIs, and this is valid for courses in all areas. Entrepreneurial education in a practical context, as in the case of a junior company, can increase entrepreneurial intention.

Originality/value - This research fills a research gap on the uncertainty of the effectiveness of entrepreneurial education in developing the entrepreneurial behavior and entrepreneurial intention of students, at least when considering the junior company as part of entrepreneurial education in the university context, presenting a robust quantitative methodology and a large sample in a developing country.
\end{abstract}

Keywords Entrepreneurial intention, Brazil, Entrepreneurial behavior, Entrepreneurial profile, Junior enterprise

Paper type Research paper

\section{Introduction}

Entrepreneurship is deemed as the process of creating ventures and, therefore, it is a planned activity (Shi, Yao, \& Wu, 2020). Because of their potential to encourage economic growth,

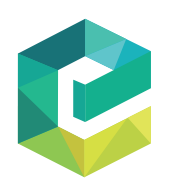

(c) Gustavo Hermínio Salati Marcondes de Moraes, Edson Sadao Iizuka, Anne Kathleen Lopes da Rocha and Amanda Mecchi Diaféria. Published in Innovation \& Management Review. Published by Emerald Publishing Limited. This article is published under the Creative Commons Attribution (CC BY 4.0) licence. Anyone may reproduce, distribute, translate and create derivative works of this article (for both commercial and non-commercial purposes), subject to full attribution to the original publication and authors. The full terms of this licence maybe seen at http://creativecommons.org/licences/by/4.0/ legalcode

The authors thank Espaco da Escrita, Coordenadoria Geral da Universidade Unicamp, for the language services provided.
Innovation \& Management Review Vol. 19 No. 2, 2022 pp. 156-172

Emerald Publishing Limited 2515-8961

DOI 10.1108/INMR-09-2020-0119 
social development and provision of jobs, governments and educational institutions devote efforts and invest large amounts of financial resources to promote entrepreneurial behavior (Rocha \& Freitas, 2014; Shi et al., 2020). Resuming the academic interest in exploring the entrepreneurial profile, this research is focused on individual agents and entrepreneurs, and how their actions and behaviors are shaped (Acs et al., 2017; Schmidt \& Bohnenberger, 2009), considering that common characteristics are attributed to these individuals (Krakauer et al., 2018; Moraes, Iizuka, \& Pedro, 2018; Rocha \& Freitas, 2014; Schmidt \& Bohnenberger, 2009).

No consensus has been reached regarding the complete set of characteristics that define entrepreneurs as a group and consolidate their nomenclature (Moraes et al., 2018; Ozaralli \& Rivenburgh, 2016; Zhao, Hills, \& Seibert, 2005). While some authors rather use personality traits (Zhao \& Seibert, 2006; Fragoso et al., 2020), others use the entrepreneurial profile nomenclature (lizuka \& de Moraes, 2014; Rocha \& Freitas, 2014). Given that our research focuses on more generic aspects of how entrepreneurs behave (Filion, 1994), this study adopts the term entrepreneur profile. In this sense, in the entrepreneur profile, entrepreneurial characteristics represent the skills and traits that an entrepreneur must have to successfully manage a business (Atiya et al., 2019). Among the most commonly reported entrepreneurial characteristics, we mention the following attitudinal aspects: self-efficacy, leadership, planner, sociability, innovative and to take calculated risks.

Another point worth mentioning is how entrepreneurial intentions are manifested, considering it is one of the factors that lead individuals to perform business activities (Aleksandrova, Gerry, \& Verkhovskaya, 2020). The theory of planned behavior (TPB), formulated by Ajzen (1991), is a major theory explaining such manifestation, which formulates a causal relationship between entrepreneurial intention and entrepreneurship itself (Ajzen, 1991; Liñán \& Fayolle, 2015).

At the same time, although entrepreneurial education is defined as a process of developing attitudes and skills for building the entrepreneurial profile (Amaral et al., 2018), its efficacy in promoting students' entrepreneurial intentions is still uncertain (Shi et al., 2020). This points to the need for evaluating mechanisms that ensure education efficiency in cultivating entrepreneurial behavior, such as participating in small companies or junior consultancies, for assisting the process of learning how to perform business activities (Shi et al., 2020). Although participating in junior enterprises may positively influence the development of entrepreneurial behaviors among young people (Barba-Sánchez \& Atienza-Sahuquillo, 2018), this field of study, which depends on an experimental learning, is still little explored, and research on entrepreneurial skills are still scarce (Johansen, 2016; Grewe \& Brahm, 2020). This is particularly true for the context of developing countries, which reproduce practices adopted in advanced economies without properly assessing their adequacy (Fischer et al., 2019; Moraes et al., 2020; Guerrero et al., 2018; Vodă \& Florea, 2019).

Junior enterprises emerged in the 1980s and, according to data collected by the Brazilian Confederation of Junior Enterprises (Confederação Brasileira de Empresas Júniores - Brasil Júnior), more than 400 junior enterprises and more than 11,000 junior entrepreneurs are established throughout Brazil, which may be associated with more than 17 states. This research aimed to analyze the influence of the junior enterprise environment on the entrepreneurial behavior of university students. For that, we intend to answer the following questions: What is the influence of the junior enterprise environment on entrepreneurial profile and entrepreneurial intention? What differs between the entrepreneurial behavior of students who participated participate in junior enterprises and those who did not?

From an academic point of view, this research helps to understand the impact of entrepreneurial education on the development of human capital (Cranmer, 2006; Sin \& Neave, 2016; Nowiński et al., 2019), highlighting the most impacted characteristics by junior enterprise environment. From a practical point of view, this research can provide higher education institutions (HEI) a more accurate understanding of junior enterprises role in 
INMR

19,2

158

stimulating university entrepreneurship. Stimulating junior companies can be a fundamental action to implement an effective entrepreneurial education within HEIs, and this is valid for courses in all fields. In a practical context, as in a junior company, entrepreneurial education may motivate entrepreneurial intention.

This paper is organized in six sections, being this introduction the first one. Section 2 establishes relations between literature of entrepreneurial profile and entrepreneurial intention and the junior enterprise environment. Section 3 presents the research model and the study hypotheses. Section 4 presents the methodological aspects, discussed and analyzed in Section 5. Section 6 presents the final considerations, limitations and suggestions for further research.

\section{Literature review}

The literature review is structured in three fundamental topics for contextualizing the research. We begin by presenting the entrepreneurial profile and the main characteristics defining it. Subsequently, we address the main models used to measure entrepreneurial intention. Finally, we explore the environment of the junior enterprise, especially in Brazil.

\subsection{Entrepreneurial profile}

The entrepreneurial profile has been the focus of research aiming to identify characteristics and skills common to individuals who perform entrepreneurial activities (Moraes et al., 2018). According to Salisu et al. (2020), this is an increasing interest especially in developing economies, and its purpose is to demonstrate which factors and characteristics may be linked to entrepreneurial efforts.

Amaral et al. (2018) state that some individuals are born with several traits considered entrepreneurial, whereas others develop them in a teaching/learning process. Regardless, it might be worth identifying characteristics and skills shared by individuals complying with entrepreneurial prerogatives (lizuka \& de Moraes, 2014; Rocha \& Freitas, 2014).

Although several behaviors are associated with the entrepreneurial profile (Krakauer et al., 2018), we delimited our scope to some behavioral characteristics (Table 1) established in previous studies (Krakauer et al., 2018; Moraes et al., 2018; Rocha \& Freitas, 2014; Schmidt \& Bohnenberger, 2009).

\subsection{Entrepreneurial intention}

Liu et al. (2020) state that entrepreneurial intention is influenced by several factors, such as individual profile and demographic aspects. Accordingly, Shi et al. (2020) state that such intention is underlined by many determinants and is the main factor influencing entrepreneurship, despite not necessarily resulting in an entrepreneurial activity per se (Aleksandrova et al., 2020).

Aleksandrova et al. (2020) understand that the decision to become an entrepreneur is a personal choice that results from a set of other intentions formed within economic, historical, cultural and institutional contexts specific to every country.

Studies such as those conducted by Shapero and Sokol (1982) and Ajzen (1991) are seminal for understanding that intentions reflect motivational factors influencing entrepreneurial behavior and shaping its planning, so that the stronger the intention to display a behavior, the greater its probability of being displayed (Aleksandrova et al., 2020). Therefore, these authors postulate that intentions produce the entrepreneurial behavior.

According to Ajzen (1991), intentions result from attitudes (individuals' attitudes toward behavior); subjective norms (norms and expectations of society in relation to their behavior); 


\begin{tabular}{|c|c|c|c|}
\hline Characteristics & Explanation of the indicator & References & $r$ \\
\hline Self-efficacy (SE) & $\begin{array}{l}\text { It is the cognitive estimation that a person } \\
\text { has to intentionally achieve results. It } \\
\text { concerns the ability to mobilize motivation, } \\
\text { cognitive resources, and courses of action } \\
\text { required to exercise control over events in } \\
\text { your life }\end{array}$ & $\begin{array}{l}\text { Moraes et al. (2018); Rocha and Freitas } \\
\text { (2014); Schmidt and Bohnenberger (2009) }\end{array}$ & 159 \\
\hline Leadership (LE) & $\begin{array}{l}\text { People who, based on their own goal, } \\
\text { influence others to voluntarily adopt this } \\
\text { goal }\end{array}$ & $\begin{array}{l}\text { Krakauer et. al (2018); Moraes et al. (2018); } \\
\text { Rocha and Freitas (2014); Schmidt and } \\
\text { Bohnenberger (2009) }\end{array}$ & \\
\hline Planner (PL) & $\begin{array}{l}\text { People who organize and prepare } \\
\text { themselves to achieve a future goal. It } \\
\text { concerns people who anticipate the facts } \\
\text { and have a future vision of the } \\
\text { organization }\end{array}$ & $\begin{array}{l}\text { Krakauer et. al (2018); Moraes et al. (2018); } \\
\text { Rocha and Freitas (2014); Schmidt and } \\
\text { Bohnenberger (2009) }\end{array}$ & \\
\hline Innovative (IN) & $\begin{array}{l}\text { People who relate ideas, facts, needs and } \\
\text { market demands in a creative way }\end{array}$ & $\begin{array}{l}\text { Moraes et al. (2018); Rocha and Freitas } \\
\text { (2014); Schmidt and Bohnenberger (2009) }\end{array}$ & \\
\hline $\begin{array}{l}\text { Takes calculated } \\
\text { risks (TR) }\end{array}$ & $\begin{array}{l}\text { People who, in the face of a personal } \\
\text { project, relate and analyze variables that } \\
\text { can influence its result, deciding, upon this, } \\
\text { on the continuity of the project. It refers to } \\
\text { individuals able to intelligently take risks, } \\
\text { to act quickly and efficiently to adapt to the } \\
\text { continuous changes in the economic } \\
\text { environment }\end{array}$ & $\begin{array}{l}\text { Moraes et al. (2018); Rocha and Freitas } \\
\text { (2014); Schmidt and Bohnenberger (2009) }\end{array}$ & \\
\hline Sociability (SO) & $\begin{array}{l}\text { Degree of use of social networks to support } \\
\text { the professional activity }\end{array}$ & $\begin{array}{l}\text { Krakauer et. al (2018); Moraes et al. (2018); } \\
\text { Rocha and Freitas (2014); Schmidt and } \\
\text { Bohnenberger (2009) }\end{array}$ & $\begin{array}{r}\text { Table 1. } \\
\text { Behavioral } \\
\text { characteristics of }\end{array}$ \\
\hline
\end{tabular}

and from the perceived behavioral control (perceived facility with which individuals believe a behavior can be successfully displayed).

Although entrepreneurial behavior is also a product of effectuation, we understand entrepreneurial intention as associated with the planned decision of running a business, the propensity to act accordingly, and the individual perception of how attainable the objectives are. (Aleksandrova et al., 2020).

Thus, we present the first research hypothesis:

H1. The entrepreneurial profile positively influences the entrepreneurial intention.

\subsection{Junior enterprise environment}

Universities play a key role in teaching, research and extension (Moraes et al., 2018). According to Rocha and Freitas (2014), entrepreneurial education comprises three pillars: developing an entrepreneurial spirit among students; training students to start and manage a business; and developing entrepreneurial skills required to identify and explore business opportunities. Therefore, entrepreneurial education takes different forms and encompasses multiple contents in the learning process, requiring different pedagogical initiatives, such as extension activities.

Extension activities include several activities that allow students to practice entrepreneurship, such as lectures, events, business incubators, junior companies and other student organizations (Moraes et al., 2018). 
INMR

19,2

In this context, the junior enterprise excels. According to the Brazilian Law No. 13,267, junior enterprise are entities managed by undergraduate students aiming to conduct projects and services that contribute to the academic and professional development of associates, training them for the labor market. It is a relevant alternative for students to practice their knowledge and exercise entrepreneurship:

Art. 5th. The junior enterprise, whose purposes are educational and nonprofit, shall have, in addition to other specific purposes, the following objectives:

I - to provide its members with the necessary conditions for the practical application of theoretical knowledge related to the respective area of professional training, offering them the opportunity to experience the labor market during their training for the exercise of the future profession and stimulating their critical, analytical, and entrepreneurial spirit; [ . . ] (Brasil, 2016).

As a pedagogical practice of entrepreneurship education, junior enterprises are a valid teaching strategy owing to its fomenting nature; besides stimulating students' entrepreneurial spirit (Almeida et al., 2019). These practices endow students with "know-how," so that their behavior corroborates the knowledge, skills and attitudes forming the entrepreneurial subject (Almeida et al., 2019; Rocha \& Freitas, 2014).

Thus, we present the second, third and fourth research hypotheses:

H2. Participating in the junior enterprise environment positively influences entrepreneurial profile.

H3. Participating in the junior enterprise environment positively influences entrepreneurial intention.

H4. The entrepreneurial profile characteristics of students who participated in junior enterprises exerted different influence on their entrepreneurial intention in relation to those who did not participate.

\section{Conceptual model}

Based on the literature review, we elaborated a model (Figure 1) and formulated hypotheses to answer the research objective. With that, we aim to understand how the junior enterprise environment influences the entrepreneurial profile and entrepreneurial intention of university students and how the entrepreneurial behavior of students who participated in junior enterprises differ from those who did not.

As the entrepreneurial profile is a hierarchical latent variable, i.e. a second-order construct, the relationships between its forming constructs are not presented as a hypothesis. Operationalization-related details of this construct are presented in the methodological section.

The presented model was based on the construction of an entrepreneurial profile (Schmidt \& Bohnenberger, 2009; Rocha \& Freitas, 2014; Moraes et al., 2018; Krakauer et al., 2018) that positively influences entrepreneurial intention (Moraes et al., 2018; Krakauer et al., 2018) and Junior enterprise environment. In turn, the junior enterprise environment is based on the university environment construct (Moraes et al., 2018, 2020), which positively influences entrepreneurial profile and intention (Saeed et al., 2015; Turker \& Selcuk, 2009; Moraes et al., 2018).

Besides the three hypotheses presented in Part A of the conceptual model, Part B presents a fourth hypothesis (H4). In H4, we analyze, by a multigroup analysis (Hair et al., 2018), whether the entrepreneurial profile characteristics of students who participated in junior enterprises exert different influence on entrepreneurial intention in relation to students who did not participate in junior enterprises. 
Part A

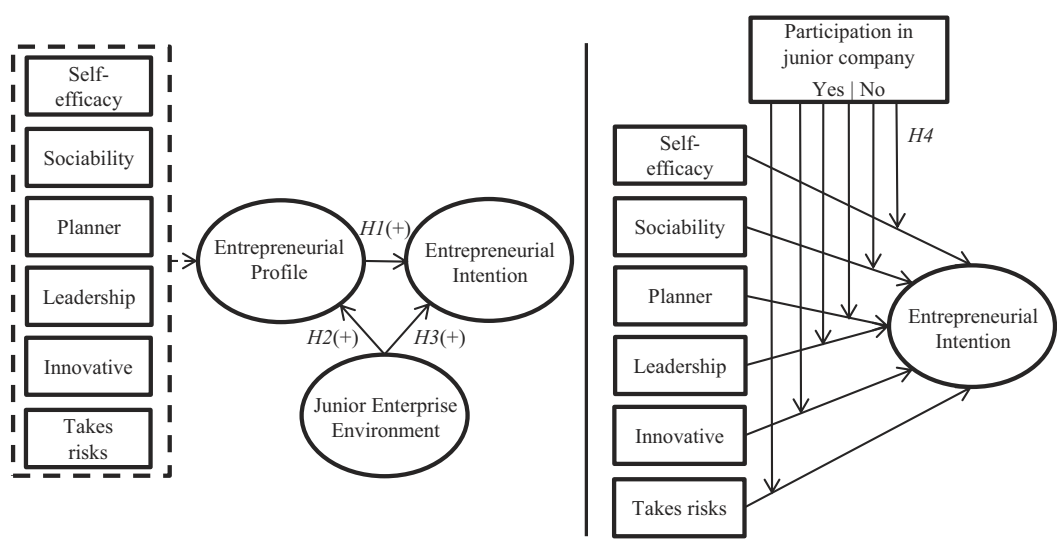

Source: Prepared by the authors
Part B

Junior enterprise

161

Figure 1.

Conceptual research models

Some indicators used in the questionnaire (self-efficacy, risk-taking, innovation, leadership, planning and sociability) consisted in validated scales of the research conducted by Rocha and Freitas (2014) and Schmidt and Bohnenberger (2009). Questions about entrepreneurial intention were adapted from Liñán and Chen (2009) and Saeed et al. (2015). The junior enterprise construct was mainly based on the studies of Schwarz et al. (2009), Saeed et al. (2015) and Moraes et al. (2018).

Experts in entrepreneurship and structural equation modeling assisted in preparing the conceptual model and validating the questionnaire.

\section{Methodological aspects}

We adopted a quantitative methodology, using structural equation modeling, to predict and explain the presented constructs. The proposed conceptual model has a hierarchical latent variable, which justifies the choice of the Partial Least Squares Structural Equation Modeling (PLS-SEM), according to the suggestions of Hair et al. (2017). Another reason for using the PLS-SEM is the fact that the model comprises reflective and formative measures (Hair et al., 2017).

Junior enterprises throughout the country were surveyed; among the 140 enterprises identified, 56 answered the research questions.

The sample included companies from all regions of Brazil: $59 \%$ were from southeastern states (Espirito Santo, Minas Gerais, Rio de Janeiro and São Paulo); 18\%, from the South (Paraná, Rio Grande do Sul and Santa Catarina); 14\%, from the Northeast (Bahia, Ceará, Pernambuco, Piauí and Rio Grande do Norte); 7\%, from the Midwest (Federal District, Goiás and Mato Grosso do Sul); and 2\%, from the North (Amazonas).

Based on the literature data, we developed a questionnaire to measure entrepreneurial profile, entrepreneurial intention and the contribution of the participation in junior enterprises by selected indicators. Given that some of the indicators used in the questionnaire were adapted by the researchers and others were extracted from the literature, a confirmatory factor analysis (CFA) was performed to confirm that the selected items would provide sufficient 
INMR

19,2

measures for the proposed constructs. The indicators were linked to loadings in their respective construct and were tested on the same model (Brady \& Cronin, 2001).

Initially, all measurements with factor loadings greater than 0.7 were maintained and measurements with factor loadings below 0.4 were excluded (Hair et al., 2017). Measurements between 0.4 and 0.7 were analyzed according to the impact on average variance extraction (AVE) and composite reliability (CR). In this sense, only the SE2 indicator had to be excluded. Table 2 shows the CFA results and descriptive analyses.

Sample size and statistical power were analyzed using the G*Power 3.1 software (Faul et al., 2009), and the minimum sample size calculated was 98 . The final sample consisted of 549 respondents (287 students participating in Junior Enterprises and 262 nonparticipants), appropriate for estimation using PLS-SEM. The post hoc analyses showed that: any $r^{2}$ higher than $2.45 \%$ would be considered significant; and the power for average effect size is 0.999 .

Data was collected using a questionnaire with closed-ended questions (Table 4) and a fivepoint Likert scale. The online version of the questionnaire was made available by the Qualtrics platform for all 140 registered companies, from its own database, via email, social networks and website.

The questionnaire was applied with the aid of important partners: State Federations of Junior Enterprises; Junior enterprises and entrepreneurs; and National Association of Undergraduate Programs in Business (Associação Nacional dos Cursos de Graduação em Administração - ANGRAD).

The SmartPLS 3.0.M3 software (Ringle \& Becker, 2015) was used to estimate and validate statistical tests developed by the structural equation modeling.

\section{Description and analysis of results}

Among the 549 respondents, 287 were junior entrepreneurs working in 56 companies across the country. The most representative states were São Paulo (29\%), Minas Gerais (25\%), Santa Catarina (9\%), Rio de Janeiro ( $8 \%$ ) and Amazonas (5\%). In total, $52 \%$ of the respondents were women and $48 \%$ men and most of them reported being single (97\%). Regarding age, $39 \%$ of the sample was composed of students aged up to 19 years; $44 \%$ of those aged between 20 and 22 ; and the remaining $(17 \%)$ were older than 23 years.

As for the period participating in the junior enterprise, $37 \%$ of the students have been working for less than 6 months; $27 \%$ between 6 months and 1 year; $27 \%$ between 1 and 2 years; and $9 \%$, for more than 2 years.

Only 67 students reported not having participating in the aforementioned activities before joining the junior enterprise, corroborating the idea that a more diversified set of performed activities increases the student's entrepreneurial potential. In addition, $38 \%$ of the students did some kind of volunteer work and $51 \%$ had worked in a family, third-party or selfemployed company.

For analyzing the results, we initially considered only respondents who participated in junior enterprises. Respondents who did not participate comprised a control group to validate the multigroup analysis (H4), presented in the final part of the section. Nonparticipants did not have to answer the part of the questionnaire concerning junior enterprises.

The cross-loadings of each indicator were analyzed to verify whether indicators associated with each construct really reflect their concept (Hair et al., 2017).

For indicators to be maintained in the model, their factor loadings must be higher than or equal to 0.7 and higher than other constructs cross-loadings (Hair et al., 2017). Factor loadings lower than 0.4 caused the indicator to be automatically excluded, as occurred with SE2, SE3 and PL1 indicators. As LE1 presented factor loading lower than 0.7 but higher than 0.4 , we considered Hair et al. (2017) suggestion to analyze how the indicator exclusion would impact 


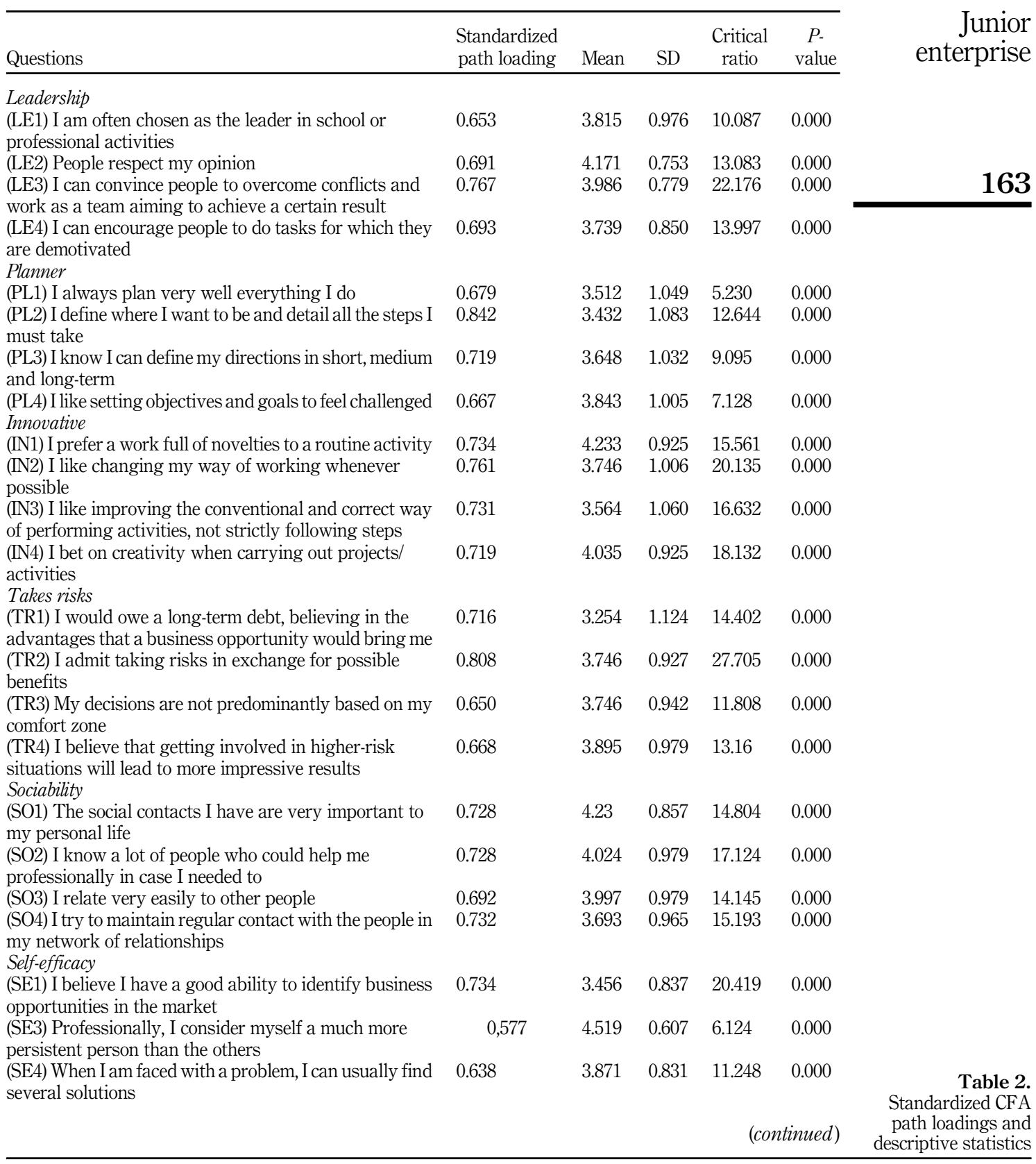


INMR 19,2

164

\begin{tabular}{|c|c|c|c|c|c|}
\hline Questions & $\begin{array}{l}\text { Standardized } \\
\text { path loading }\end{array}$ & Mean & SD & $\begin{array}{l}\text { Critical } \\
\text { ratio }\end{array}$ & $\begin{array}{c}P- \\
\text { value }\end{array}$ \\
\hline $\begin{array}{l}\text { (SE5) I can solve most problems if I devote the necessary } \\
\text { effort }\end{array}$ & 0.792 & 3.756 & 0.763 & 25.309 & 0.000 \\
\hline \multicolumn{6}{|l|}{ Entrepreneurial Intention } \\
\hline ly to do anythi & 0.755 & 3.418 & 1.159 & 23.598 & 0.000 \\
\hline $\begin{array}{l}\text { (EI2) I will make every effort to create and maintain my } \\
\text { own company }\end{array}$ & 0.901 & 3.477 & 1.311 & 72.745 & 0.000 \\
\hline $\begin{array}{l}\text { (EI3) Even if I work for other companies, I will never } \\
\text { abandon my dream of starting my own business }\end{array}$ & 0.887 & 3.24 & 1.387 & 60.242 & 0.000 \\
\hline $\begin{array}{l}\text { (EI4) My greatest accomplishment will be having my } \\
\text { own business }\end{array}$ & 0.895 & 2.895 & 1.483 & 58.261 & 0.000 \\
\hline $\begin{array}{l}\text { (EI5) I intend to start a business in the next few years } \\
\text { Junior Enterprise Environment }\end{array}$ & 0.865 & 3.000 & 1.528 & 49.660 & 0.000 \\
\hline $\begin{array}{l}\text { (JEE1) The Junior Enterprise helped me to detect } \\
\text { business opportunities and be persistent }\end{array}$ & 0.748 & 4.303 & 0.734 & 27.840 & 0.000 \\
\hline $\begin{array}{l}\text { (JEE2) I developed my leadership skills through group } \\
\text { work in the Junior Enterprise }\end{array}$ & 0.750 & 4.509 & 0.683 & 22.050 & 0.000 \\
\hline $\begin{array}{l}\text { (JEE3) The Junior Enterprise provided me with planning } \\
\text { and strategy tasks in different disciplines, thus } \\
\text { developing my ability to plan }\end{array}$ & 0.757 & 4.484 & 0.662 & 21.301 & 0.000 \\
\hline $\begin{array}{l}\text { (JEE4) I improved my creativity and ability to innovate } \\
\text { with the Junior Enterprise. }\end{array}$ & 0.720 & 4.286 & 0.748 & 18.944 & 0.000 \\
\hline $\begin{array}{l}\text { (JEE5) The Junior Enterprise enabled me to relate and } \\
\text { analyze the variables that influence the outcome of a } \\
\text { problem, increasing my ability to take calculated risks }\end{array}$ & 0.789 & 4.258 & 0.753 & 33.244 & 0.000 \\
\hline $\begin{array}{l}\text { (JEE6) The Junior Enterprise provided me with several } \\
\text { important contacts in person and professional terms }\end{array}$ & 0.675 & 4.439 & 0.705 & 14.671 & 0.000 \\
\hline (JEE7) The Junior Enterprise motivated me to want to & 0.547 & 3.871 & 0.952 & 10.244 & 0.000 \\
\hline
\end{tabular}

Table 2. start my own business

Source: Prepared by the authors

the average variance extracted (AVE) and composite reliability, which led us to exclude the LE1 indicator as well.

Our research model presents a hierarchical latent variable (entrepreneurial profile). Hierarchical latent variable models are characterized by the number of levels in the model and by the relationships between its constructs (Becker, Klein, \& Wetzels, 2012). A second-order construct is a general concept that is formed (formative) or represented (reflective) by first-order constructs. Therefore, the relationship between second- and first-order constructs is not of dependence, but rather of hierarchy, as the second-order construct does not exist without the first-order constructs (Becker et al., 2012).

In our research model, the entrepreneurial profile is a second-order construct (higher-order constructs - HOCs) formed by the first-order constructs (lower-order constructs - LOCs) selfefficacy, risk-taking, innovation, leadership, planning and sociability. Because of the characteristic of the model, the two-stage approach was adopted to estimate the parameters (Hair et al., 2018), which was performed with the aid of the SmartPLS 3.0.M3 software (Ringle \& Becker, 2015).

In this approach, analyses are separated into two stages: ideally, for the first one, the repeated indicator approach should be used to obtain constructs scores (Hair et al., 2018), which were tabulated as additional variables for further analysis in the second stage; in the 
second stage, the LOCs scores obtained in the previous stage were used as indicators for HOCs (Hair et al., 2018).

Our research model has two formative indicators (entrepreneurial profile and junior enterprise) and one reflective indicator (entrepreneurial intention), so that each indicator will be evaluated according to appropriate criteria.

According to Hair et al. (2017), the evaluation criteria for the formative model are: convergent validity, multicollinearity analysis and significance and relevance.

Convergent validity was assessed by redundancy analysis, which correlated the formative construct variables with a global measure of the indicator. The constructs were modeled as independent variable and the global measure as dependent variable (Hair et al., 2017). Path coefficient above the threshold value of 0.80 supports the formative construct convergent validity. The path coefficient for the entrepreneurial profile construct was 0.805 and for the junior enterprise construct 0.813 , supporting their convergent validity.

The variance inflation factor (VIF) of the formative constructs variables was analyzed to test the collinearity of indicators, showing values within those established by Hair et al. (2017) - lower than 5 .

Significance and relevance were analyzed using the bootstrap method, and all indicators showed significance according to the T-statistic of outer weights, being maintained in the constructs (Hair et al., 2017).

Reflective models were analyzed based on the internal consistency, indicator reliability, convergent validity and discriminant validity (Hair et al., 2017).

Discriminant validity and convergent validity were evaluated at the level of indicators and latent variables (Hair et al., 2017). After the dimensional analysis, all indicators remaining presented factor loadings higher than 0.70 in their latent variables (convergent validity) and low factor loadings in other latent variables (discriminant validity).

The AVE was also used in the model convergent validity, which must present a value greater than 0.5 (Hair et al., 2017).

Each construct composite reliability is one of the measures used to evaluate the measurement model (Hair et al., 2017). Composite reliability describes the degree to which indicators represent a common latent construct, and 0.70 is a commonly used reference value to indicate acceptable reliability.

The construct internal consistency was analyzed using Cronbach's alpha, whereby a high value indicates that all variables represent the same latent construct. For exploratory studies, values between 0.60 and 0.70 are considered acceptable (Nunally \& Bernstein, 1994; Hair et al., 2017).

Yet another criterion to discriminate validity is calculating the square root of AVE and comparing it with the correlation among latent variables (Fornell \& Larcker, 1981).

Table 3 shows all indicators, within the values established by the authors. The square root of AVE is shown diagonally, in bold.

The structural model was analyzed by collinearity, based on the tolerance analysis and VIF. All tolerance values were above 0.2 and VIF below 5 (Hair et al., 2017).

Indicators significance was analyzed based on a modeling estimate using the bootstrap method (Efron \& Tibshirani, 1998), which also estimates parameter and their confidence intervals based on multiple estimates (Hair et al., 2017).

According to the Student's $t$-test ( $t$-values) hypothesis, correlation coefficients are equal to zero. All values of the relationships presented Student's $t$-values higher than $1.96(5 \%$ significance level).

The coefficient of determination $\left(R^{2}\right)$ was evaluated based on a study conducted by Cohen (1988), whereby $R^{2}$ equal to $2 \%$ is considered small effect sizes, $13 \%$ medium and $25 \%$ are large. 
INMR

19,2

166
The entrepreneurial intention construct showed $R^{2}$ equal to 0.385 , considered high, and the entrepreneurial profile construct showed $R^{2}$ equal 0.224, also considered high. Figure 2 presents the resulting model.

The $\mathrm{Q}^{2}$ value, an indicator of the model predictive relevance, was also assessed. $\mathrm{Q}^{2}$ values higher than zero for a specific endogenous latent variable demonstrate relevance of the SEM path model. All values are considered adequate.

A multigroup analysis was conducted to test our study hypothesis regarding the difference in the relationships between the entrepreneurial profile characteristics of students who participated in junior enterprises and their entrepreneurial intention when compared to those who did not participate.

Table 4 shows the results regarding significant construct relationships between groups of respondents who participated and who did not participate in a junior enterprise (Figure 1 shows the Part B of the conceptual model).

\begin{tabular}{lccc}
\hline Constructs & Junior enterprise & Entrepreneurial intention & Entrepreneurial profile \\
\hline Junior enterprise & Formative & & \\
$\begin{array}{l}\text { Entrepreneurial intention } \\
\text { Entrepreneurial profile }\end{array}$ & 0.475 & 0.863 & \\
& 0.474 & 0.581 & Formative \\
$\begin{array}{l}\text { Cronbach's alpha } \\
\text { Composite reliability }\end{array}$ & Formative & 0.913 & Formative \\
$\begin{array}{l}\text { Average variance extracted } \\
\text { Source: Prepared by the authors }\end{array}$ & Formative & 0.936 & Formative \\
& & 0.745 & Formative \\
\hline
\end{tabular}

Table 3.

Synthesis of the evaluation of the measurement model
Part A

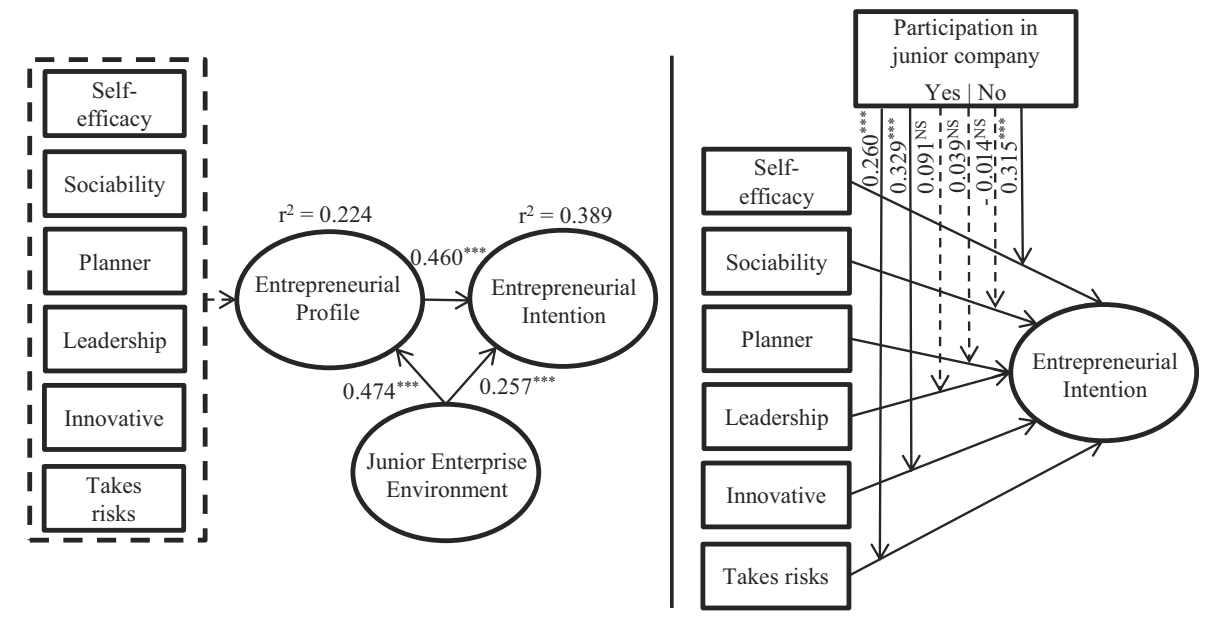

Notes: NS $=$ Nonsignificant $; *=$ Significant at $5 \% ; * *=$ Significant at $1 \% ; * * *=$ Significant at $0.1 \%$

Source: Prepared by the authors
Figure 2.

Models resulting from the research 
Table 4 data enable us to verify significant differences in the relationships between selfefficacy, innovation and risk-taking toward entrepreneurial intention, positively greater for students who participated in the junior enterprise. In turn, leadership, planning and sociability indicators showed no significant differences between groups regarding Entrepreneurial Intention.

Table 5 shows the synthesis of the hypothesis testing.

\section{Discussion}

This research sought to analyze the influence of participating in a junior enterprise on the entrepreneurial profile and entrepreneurial intention of university students, as well as the difference in the entrepreneurial behavior of students who participated and students who did not participate in these.

The university environment is an important factor in stimulating student entrepreneurship (Moraes et al., 2020). This is owing to the fact that universities mobilize infrastructure, mechanisms and programs to encourage entrepreneurship in the academic community (Guerrero et al., 2018), including supporting junior companies (Johansen, 2016; Grewe \& Brahm, 2020). Within this context, this study presents a robust and consistent model with a high explanatory power of the entrepreneurial profile and entrepreneurial intention constructs, confirming a positive influence of the junior enterprise environment on the development of these characteristics. We also found participating in a junior enterprise to foster the development of certain entrepreneurial characteristics.

\begin{tabular}{|c|c|c|}
\hline Relationships & Difference in coefficients (JE vs NJE) & $P$-value \\
\hline Self-efficacy $\rightarrow$ entrepreneurial intention & 0.315 & 0.000 \\
\hline Sociability $\rightarrow$ entrepreneurial intention & $-0,014$ & 0.857 \\
\hline Planner $\rightarrow$ entrepreneurial intention & 0.039 & 0.575 \\
\hline Leadership $\rightarrow$ entrepreneurial intention & 0.091 & 0.217 \\
\hline Innovative $\rightarrow$ entrepreneurial intention & 0.329 & 0.000 \\
\hline Takes risks $\rightarrow$ entrepreneurial intention & 0.260 & 0.001 \\
\hline
\end{tabular}

Notes: JE: Junior enterprise participants; NJE: Nonparticipants of junior enterprises

Source: Prepared by the authors

\section{Junior enterprise}

Table 4.

Analysis of relationships per differentiation of participation or not in junior enterprises

\begin{tabular}{|c|c|c|}
\hline Hypotheses & Description & Result \\
\hline$H 1$ & The Entrepreneurial Profile positively influences the Entrepreneurial Intention & Confirmed \\
\hline$H 2$ & $\begin{array}{l}\text { Participation in the Junior Enterprise Environment positively influences the } \\
\text { Entrepreneurial Profile }\end{array}$ & Confirmed \\
\hline$H 3$ & $\begin{array}{l}\text { Participation in the Junior Enterprise Environment positively influences the } \\
\text { Entrepreneurial Intention }\end{array}$ & Confirmed \\
\hline$H 4$ & $\begin{array}{l}\text { There are differences in the influence of the characteristics of Entrepreneurial } \\
\text { Profile on Entrepreneurial Intention between students who participated and } \\
\text { students who did not participate in junior enterprises }\end{array}$ & $\begin{array}{l}\text { Partially } \\
\text { confirmed }\end{array}$ \\
\hline
\end{tabular}

Source: Prepared by the authors
Table 5.

Synthesis of results of the study hypotheses 
INMR

19,2

168
The results obtained from data on all regions of a developing country enable us to present two main contributions. First, that participating in junior enterprises influences the development of students' entrepreneurial profile more than their entrepreneurial intention. Our results show that participating in junior enterprises influence both entrepreneurial profile and intention, but its influence on entrepreneurial profile is more considerable. This is an important contribution for demonstrating that junior companies are fulfilling their role in the professional development and training of associates for the labor market (whether on their own business or not), stimulating students' entrepreneurial spirit (Almeida et al., 2019).

The second contribution is to present which behavioral characteristics are mostly developed by participating in a junior enterprise. The most developed characteristic is that related to innovation, creatively relating idea, facts, needs and market demands. The second most developed characteristic is self-efficacy, increasing the ability to mobilize motivation, cognitive resources and courses of action required to exercise control over life events. Finally, the ability to take risks was also greatly developed, improving the ability to analyze variables that can influence decisions.

Students who participate in junior enterprises often present a strong entrepreneurial motivation. However, some of the students in our sample had no intention to become an entrepreneur despite participating in a junior enterprise. This finding highlights the need for a company to have people with different profiles and skills, complementing each other.

We believe our study to contribute in advancing knowledge about entrepreneurial behavior, as well as about Brazilian junior enterprises, increasingly growing in the universities of the country. From a practical perspective, we sought to provide HEI with a more accurate understanding of the role of junior enterprises in stimulating university entrepreneurship, as well as raise junior enterprises and entrepreneurs' awareness for management-related and self-knowledge purposes. Our results reinforce that stimulating junior companies can be a fundamental action for implementing an effective entrepreneurial education within the HEIs, and this is valid for courses in all fields, as multidisciplinary teams in junior companies approach the labor market reality (Barba-Sánchez \& Atienza-Sahuquillo, 2018). In this sense, Piperopoulos and Dimov (2015) argue that teaching entrepreneurship in a theoretical context may reduce entrepreneurial intention, although increasing student selfefficacy; in turn, in a practical context - as in the case of a junior company - it may increase such intention.

\section{Conclusions}

The junior company movement emerged as a way to assist entrepreneurial learning and increase entrepreneurship among students, with new job prospects for students from all fields of expertise (Barba-Sánchez \& Atienza-Sahuquillo, 2018). Being immersed in commercial initiatives to improve productivity in the workplace and career options, learning the role of economics in society, is convenient for any student (Violante \& Vezzetti, 2017). Thus, the experience as junior entrepreneurs make future employees more capable of taking advantage of opportunities and establishing a social or commercial activity, besides increasing awareness about their role in the global context and in the labor market (Barba-Sánchez \& AtienzaSahuquillo, 2018).

This research fills a knowledge gap regarding uncertainty of entrepreneurial education efficiency in developing students' entrepreneurial behavior and intention (Shi et al., 2020) in the context of the junior company as part of entrepreneurial education within the university, presenting a robust quantitative method and a large sample in a developing country. 
Our study has some limitations, such as the use of a questionnaire with perceived conditions and self-assessment indicators, which may present biased results. Data was collected by a single cross-sectional research design, which makes it difficult to analyze how the association between variables of interest evolves over time. Moreover, we did not use a probabilistic sampling as research scope.

We suggest further studies to be conducted longitudinally, addressing the relationship between junior enterprise environment and entrepreneurial behavior, considering differences in regions, gender or academic courses within the research context and conducting a qualitative research with junior companies' participants.

\section{References}

Acs, Z. J., Audretsch, D. B., Lehmann, E. E., \& Litch, G. (2017). National systems of innovation. The Journal of Technology Transfer, 42(5), 997-1008. doi: 10.1007/s10961-016-9481-8.

Ajzen, I. (1991). The theory of planned behavior. Organizational Behavior and Human Decision Processes, 50(2), 179-211. doi: 10.1016/0749-5978(91)90020-T.

Aleksandrova, E., Gerry, C. J., \& Verkhovskaya, O. (2020). Missing entrepreneurs: The importance of attitudes and control in shaping entrepreneurial intentions in russia. Journal of Entrepreneurship in Emerging Economies, 12(1), 1-33. doi: 10.1108/JEEE-11-2018-0133.

Almeida, L. R. S. D., Cordeiro, E. D. P. B., \& Silva, J. A. G. D. (2019). Proposições acerca do ensino de empreendedorismo nas instituições de ensino superior brasileiras: Uma revisão bibliográfica. Revista de Ciências da Administração, 1(3), 109-122. doi: 10.5007/2175-8077.2018v20n52p109.

Amaral, M., Toledo Hernandez, C., Henrique, M., \& Bastos, R. (2018). The entrepreneurial profile of Brazilian business administration students. International Journal of Innovation Science, 10(2), 160-177. doi: 10.1108/JJIS-05-2017-0040.

Atiya, T. M. S., Bilal, Z. O., Abulhamid, M., \& Shoaib, S. A. (2019). The impact of entrepreneurial characteristics on entrepreneurial intention of sudanese and Omani university students. European Scientific Journal Esj, 15(4), 1857-7881. doi: 10.19044/esj.2019.v15n4p66.

Barba-Sánchez, V., \& Atienza-Sahuquillo, C. (2018). Educación emprendedora através de las junior empresas. Journal of Management and Business Education, 1(2), 106-116.https://redaedem.org/ JMBE2/num_anteriores/Vol.\%2001.\%20Num.\%202-4.\%202018.pdf doi: 10.35564/jmbe. 2018.0009.

Becker, J.-M., Klein, K., \& Wetzels, M. (2012). Hierarchical latent variable models in PLS-SEM: Guidelines for using reflective-formative type models. Long Range Planning, 45(5-6), 359-394. doi: 10.1016/j.lrp.2012.10.001.

Brady, M. K., \& Cronin, J. J. (2001). Some new thoughts on conceptualizing perceived service quality: A hierarchical approach. Journal of Marketing, 65(3), 34-49. doi: 10.1509/jmkg.65.3.34.18334.

Brasil. (2016). Lei $n^{\circ}$ 13.267, de 06 de abril de. Disciplina a criação e a organização das associações denominadas empresas juniores, com funcionamento perante instituições de ensino superior. Brasília, Retrieved from www.in.gov.br/materia//asset_publisher/Kujrw0TZC2Mb/content/id/ 21173868/do1-2016-04-07-lei-n-13-267-de-6-de-abril-de-2016-21173742.

Cohen, J. (1988). Statistical power analysis for the behavioral sciences, 2nd ed., Hillsdale, NJ: Erlbaum.

Cranmer, S. (2006). Enhancing graduate employability: Best intentions and mixed outcomes. Studies in Higher Education, 31(2), 169-184. doi: 10.1080/03075070600572041.

Efron, B., \& Tibshirani, R. J. (1998). An introduction to the bootstrap, Chapman \& Hall/CRC Press.

Faul, F., Erdfelder, E., Buchner, A., \& Lang, A.-G. (2009). Statistical power analyses using G*power 3.1: Tests for correlation and regression analyses. Behavior Research Methods, 41(4), 11491160. doi: 10.3758/BRM.41.4.1149. 
INMR 19,2

Fornell, C., \& Larcker, D. F. (1981). Evaluating structural equation models with unobservable variables and measurement error. Journal of Marketing Research, 18(1), 39-50. doi: 10.2307/ 3151312.

Fragoso, R., Rocha-Junior, W., \& Xavier, A. (2020). Determinant factors of entrepreneurial intention among university students in Brazil and Portugal. Journal of Small Business \& Entrepreneurship, 32(1), 33-57. doi: 10.1080/08276331.2018.1551459.

Grewe, U., \& Brahm, T. (2020). Development of entrepreneurial competences in mini-companies at schools. Education + Training, 62(7/8), 917-931. doi: 10.1108/ET-08-2019-0186.

Guerrero, M., Urbano, D., Cunningham, J. A., \& Gajón, E. (2018). Determinants of graduates' start-ups creation across a multi-campus entrepreneurial university: The case of monterrey institute of technology and higher education. Journal of Small Business Management, 56(1), 150-178. doi: 10.1111 jssm.12366.

Hair, J. F., Hult, G. T. M., Ringle, C. M., \& Sarstedt, M. (2017). A primer on partial least squares structural equation modeling (PLS-SEM), 2nd ed., Thousand Oaks, CA: Sage.

Hair, J. F., Sarstedt, M., Ringle, C. M., \& Gudergan, S. P. (2018). Advanced issues in partial least squares structural equation modeling (PLS-SEM, Thousand Oaks, CA: Sage.

lizuka, E. S., \& de Moraes, G. H. S. M. (2014). Análise do potencial e perfil empreendedor do estudante de administração e o ambiente universitário: Reflexões Para instituições de ensino. Administração: Ensino e Pesquisa, 15(3), 593-630. doi: 10.13058/raep.2014.v15n3.16.

Johansen, V. (2016). Gender and self-employment: The role of mini-companies. Education + Training, 58(2), 150-163. doi: 10.1108/ET-06-2015-0051.

Krakauer, P. V. C., Moraes, G. H. S. M., Coda, R., \& Berne, D. F. (2018). Brazilian women's entrepreneurial profile and intention. International Journal of Gender and Entrepreneurship, 10(4), 361-380. doi: 10.1108/IJGE-04-2018-0032.

Liñán, F., \& Chen, Y. (2009). Development and cross-cultural application of a specific instrument to measure entrepreneurial intentions. Entrepreneurship Theory and Practice, 33(3), 593-617. doi: 10.1111/j.1540-6520.2009.00318.x.

Liñán, F., \& Fayolle, A. (2015). A systematic literature review on entrepreneurial intentions: Citation, thematic analyses, and research agenda. International Entrepreneurship and Management Journal, 11(4), 907-933. doi: 10.1007/s11365-015-0356-5.

Liu, T., Walley, K., Pugh, G., \& Adkins, P. (2020). Entrepreneurship education in China evidence from a preliminary scoping study of enterprising tendency in Chinese university students. Journal of Entrepreneurship in Emerging Economies, 12(2), 305-326. doi: 10.1108/JEEE-01-2019-0006.

Moraes, G. H. S. M., Fischer, B. B., Campos, M. L., \& Schaeffer, P. R. (2020). University ecosystems and the commitment of faculty members to support entrepreneurial activities. Brazilian Administration Review (BAR), 17(2), 1-26. doi: 10.1590/1807-7692bar2020190013.

Moraes, G. H. S. M., Iizuka, E. S., \& Pedro, M. (2018). Effects of entrepreneurial characteristics and university environment on entrepreneurial intention. Revista de Administração Contemporânea, 22(2), 226-248. doi: 10.1590/1982-7849rac2018170133.

Nowiński, W., Haddoud, M. Y., Lančarič, D., Egerová, D., \& Czeglédi, C. (2019). The impact of entrepreneurship education, entrepreneurial self-efficacy and gender on entrepreneurial 
intentions of university students in the visegrad countries. Studies in Higher Education, 44(2), 361-379. doi: 10.1080/03075079.2017.1365359.

Nunally, J. C., \& Bernstein, I. (1994). Psychometric theory, New York, NY: McGraw-Hill.

Ozaralli, N., \& Rivenburgh, N. K. (2016). Entrepreneurial intention: Antecedents to entrepreneurial behavior in the U. Journal of Global Entrepreneurship Research, 6(1), 2-32. doi: 10.1186/s40497016-0047-x.

Piperopoulos, P., \& Dimov, D. (2015). Burst bubbles or build steam? Entrepreneurship education, entrepreneurial self-efficacy, and entrepreneurial intentions. Journal of Small Business Management, 53(4), 970-985. doi: 10.1111/jsbm.12116.

Ringle, C. M., \& Becker, J.-M. (2015). SmartPLS 3. Retrieved from SmartPLS 3 website: Retrieved from www.smartpls.com.

Rocha, E. L. C., \& Freitas, A. A. F. (2014). Avaliação do ensino de empreendedorismo entre estudantes universitários por meio do perfil empreendedor. Revista de Administração Contemporânea, 18(4), 465-486. doi: 10.1590/1982-7849rac20141512.

Saeed, S., Yousafzai, S. Y., Yani-De-Soriano, M., \& Muffatto, M. (2015). The role of perceived university support in the formation of students' entrepreneurial intention. Journal of Small Business Management, 53(4), 1127-1145. doi: 10.1111/jsbm.12090.

Salisu, I., Hashim, N., Shehu Mashi, M., \& Galadanchi Aliyu, H. (2020). Perseverance of effort and consistency of interest for entrepreneurial career success. Does resilience matter? Journal of Entrepreneurship in Emerging Economies, 12(2), 279-304. doi: 10.1108/JEEE-022019-0025.

Schmidt, S., \& Bohnenberger, M. C. (2009). Perfil empreendedor e desempenho organizacional. Revista de Administração Contemporânea, 13(3), 450-467. doi: 10.1590/\$1415-65552009000300007.

Shapero, A., \& Sokol, L. (1982). The social dimensions of entrepreneurship. Encyclopedia of entrepreneurship, pp. 72-90. Englewood Cliffs: Prentice-Hall.

Shi, L., Yao, X., \& Wu, W. (2020). Perceived university support, entrepreneurial self-efficacy, heterogeneous entrepreneurial intentions in entrepreneurship education the moderating role of the Chinese sense of face. Journal of Entrepreneurship in Emerging Economies, 12(2), 205-230. doi: 10.1108/JEEE-04-2019-0040.

Sin, C., \& Neave, G. (2016). Employability deconstructed: Perceptions of bologna stakeholders. Studies in Higher Education, 41(8), 1447-1462. doi: 10.1080/03075079.2014.977859.

Turker, D., \& Selcuk, S. S. (2009). Which factors affect entrepreneurial intention of university students? Journal of European Industrial Training, 33(2), 142-159. doi: 10.1108/ 03090590910939049.

Violante, M. G., \& Vezzetti, E. (2017). Guidelines to design engineering education in the twenty-first century for supporting innovative product development. European Journal of Engineering Education, 42(6), 42. doi: 10.1080/03043797.2017.1293616.

Vodă, A. I., \& Florea, N. (2019). Impact of personality traits and entrepreneurship education on entrepreneurial intentions of business and engineering students. Sustainability, 11(4), 1192. doi: 10.3390/su11041192.

Zhao, H., \& Seibert, S. E. (2006). The big five personality dimensions and entrepreneurial status: A meta-analytical review. Journal of Applied Psychology, 91(2), 259-271. doi: 10.1037/0021-9010.91. 2.259 .

Zhao, H., Hills, G. E., \& Seibert, S. E. (2005). The mediating role of self-efficacy in the development of entrepreneurial intentions. Journal of Applied Psychology, 90(6), doi: 10.1037/0021-9010.90. 6.1265 . 
INMR

19,2

\section{Further reading}

Bignotti, A., \& Le Roux, I. (2016). Unravelling the conundrum of entrepreneurial intentions, entrepreneurship education, and entrepreneurial characteristics. Acta Commercii, 16(1), a352. doi: 10.4102/ac.v16i1.352.

\section{Corresponding author}

Gustavo Hermínio Salati Marcondes de Moraes can be contacted at: salati@unicamp.br

Associate Editor: Felipe Borini

For instructions on how to order reprints of this article, please visit our website: www.emeraldgrouppublishing.com/licensing/reprints.htm Or contact us for further details: permissions@emeraldinsight.com 